\title{
Universiteit
}

Leiden

The Netherlands

\section{Islam and Democracy: What is the Real Question?} Bayat,

\section{Citation}

Bayat,. (2007). Islam and Democracy: What is the Real Question? Retrieved from https://hdl.handle.net/1887/12452

Version: $\quad$ Not Applicable (or Unknown)

License: $\quad$ Leiden University Non-exclusive license

Downloaded from: https://hdl.handle.net/1887/12452

Note: To cite this publication please use the final published version (if applicable). 
ISLAM AND DEMOCRACY:

What is the Real Question? 
The ISIM Papers represent individual lectures delivered at the International Institute for the Study of Islam in the Modern World (ISIM). The aim of this series is both to allow the papers, initially presented before limited audiences, to be shared by the entire academic community and to contribute to the further development of the study of Islam in the modern world.

IS IM PAPERS:

1. James Piscatori

Islam, Islamists, and the Electoral Principle in the Middle East

2. Talal Asad

Thinking about Secularism and Law in Egypt

3. John Bowen

Shari'a, State, and Social Norms in France and Indonesia

4. Barbara D. Metcalf

'Traditionalist' Islamic Activism: Deoband, Tablighis, and Talibs

5. Abdulaziz Sachedina

The Role of Islam in the Public Square: Guidance or Governance?

6. Lila Abu-Lughod

Local Contexts of Islamism in Popular Media

7. Juan R.I. Cole

The Ayatollahs and Democracy in Iraq

8. Asef Bayat

Islam and Democracy: What is the Real Question? 


\section{ISLAM AND DEMOCRACY}

\section{WHAT IS THE REAL QUESTION? \\ Asef Bayat}

IS IM PAPER 8

AMSTERDAM UNIVERSITY PRESS

IS I M L EIDEN 
Cover design and lay-out: De Kreeft, Amsterdam

ISBN 9789053569832

ISSN 1568-8313

NUR 717

(c) Amsterdam University Press, Amsterdam 2007

All rights reserved. Without limiting the rights under copyright reserved above, no part of this book may be reproduced, stored in or introduced into a retrieval system, or transmitted, in any form or by any means (electronic, mechanical, photocopying, recording or otherwise) without the written permission of both the copyright owner and the author of the book. 


\section{Islam and Democracy: What is the Real Question? ${ }^{1}$}

A major preoccupation of nineteenth century social theorists was to dispel the distinction between the religious and the non-religious. Now, after over a century of modernization, they are trying to differentiate between the religious and the more religious. This "over-religiosity", nowadays couched in various terms such as fundamentalism, revivalism, conservatism, fanaticism or extremism, appears to represent a global trend, which involves most of the world's major creeds. Yet in the West it has shaped a particular, negative thinking about Muslim societies in particular.

Undoubtedly, the 9/11 terrorist attacks in the US and subsequent developments have greatly intensified Western anxieties over the "threat" of "Islamic fundamentalism", and thus have reinforced more than ever the notion of the "peculiarity of Muslims". Of course, the construction of "unique" Muslims is not new: it has been the hallmark of the so-called Orientalist outlook which Edward Said and others have so remarkably and critically taken up. For Said and other critics, Orientalism represented a discursive apparatus that produced knowledge as an instrument of power, as a means

1 This text is the revised version of my inaugural lecture at Leiden University, 26 April 2005. The argument forms the core of the first chapter of my forthcoming book Making Islam Democratic: Social Movements and the Post-Islamist Turn (Stanford, Stanford University Press, 2007), in which I elaborate on the propositions developed in this text. I appreciate the permission of Stanford University Press. Further distribution, reproduction or use of this material in any way or by any means, is prohibited without the written permission of the Stanford University Press, www.sup.org. 
to maintain domination. ${ }^{2}$ It is the story of how a host of travelers, novelists, artists, diplomats, scholars and now the media depict the Muslim Middle East as a monolithic, fundamentally static, and consequently "peculiar" entity. By emphasizing the "exceptionalism" of Muslim societies in general, they focus on narrow notions of (static) culture and religion as the context of historical continuity, and on individual elites or external forces as the source of (uncommon) change.

But how "peculiar" are the Muslim societies, if they are so at all? Are they so different as to require different tools for analysis? Can we, after all, even speak of such a thing as "Muslim societies"? By employing such a broad category, are we not in a sense re-Orientalizing Muslim societies and cultures, constructing homogenous entities that do not actually exist? While such questions remain legitimate concerns, I would like to suggest that Muslim societies can be understood in such a way as to serve as a useful analytical category.

I have proposed elsewhere that the terms "Islamic world" and "Islamic society", used in singular abstract forms, may indeed imply that Islam is the central factor that shapes the dynamics of these societies. "Islamic society" becomes a generality which is constructed by others to describe Muslims and their cultures. It tells us the way in which others imagine how Muslims are and even how they should be. This worldview has been perpetuated in part by some Muslim groups (chiefly Islamists), who likewise construct a unitary Islamic landscape. In contrast, the designation "Muslim societies", understood as plural and concrete entities, allows a self-conscious Muslim majority to define their own reality in an inevitably contested, differentiated and dynamic fashion. Here the emphasis is not on Islam, but on Muslims as agents of societies and cultures, even if not of their own making. And "culture" is understood not as a set of static codes and conducts but as a series of processes, always changing, flexible and contested. These are the societies in which aspects of Islam, interpreted and adopted in diverse manners, have influenced some domains of private and public life - including the realms of morality, family relations,

2 Edward Said, Orientalism, New York: Vintage, 1979; Maxime Rodinson, Europe and the Mystique of Islam, University of Washington Press, 1987. It goes without saying that Orientalism in the Saidian sense (with a capital O) does not necessarily refer to any orientalist (with a small o) scholar who studies the "orient". Indeed there are many scholars in this discipline who contest Orientalism as a discursive machine in the service of power.

3 See: Asef Bayat, “The Use and Abuse of 'Muslim Societies'”, ISIM Newsletter, no 13, December 2003, p. 5. 
gender dynamics, law, and sometimes politics and the state. What is common among this differentiated whole is the claim of all Muslims (liberal or conservative, activist or lay persons) to "true" Islam, to the sacred texts.

Yet "Muslim societies" - as concrete entities or in reality - are never monolithic as such, never religious by definition, nor are their cultures confined to mere religion. Indeed, national cultures, historical experiences, political trajectories, as well as class affiliation, have often produced different cultures and sub-cultures of Islam, religious perceptions and practices across and within different Muslim nations. And each "Muslim" (or predominantly Muslim) country is comprised of people with various degrees of religious affiliations. In this sense, Muslim societies are quite similar to their counterparts in the developing world. Similarities are particularly compounded by the relentless process of globalization, which tends to produce not only differentiation, but also many parallel structures and processes between the nations of the globe.

Yet despite many structural resemblances, the Muslim Middle East (and now by extension Muslim world) is still measured by the "exceptionalist" yardstick of which religio-centrism is the central core. So the region's authoritarianism, "weak civil societies" and political culture are often attributed to its main religion, Islam. Although "exceptionalism" is not limited to the Muslim Middle East - we also have "American Exceptionalism", "European exceptionalism", and the "peculiarity of the English", as E.P. Thompson called it - but in the case of the Muslim Middle East, unlike the others, this characterization has often led to the marginalization of this region from mainstream scholarly perspectives.

I think that at least three factors have contributed to the "exceptionalist" outlook in the study of Muslim Middle East today. The first is the continuing prevalence of Orientalist/essentializing thought in the West, particularly in the US, which seems to converge well with the interventionist foreign policy objectives in the Middle East. The second element is the persistent authoritarian rule by the local regimes (e.g. the Shah's Iran, Saddam's Iraq, Saudi Arabia, Jordan, and Egypt), which have invariably been supported by many Western states, especially the USA. And the third factor has to do with the fact that within the Muslim region, there has been an emergence and expansion of Islamist movements that have often displayed sociallyconservative and undemocratic dispositions. These positions and processes have given rise to countless claims and counter-claims around the infamous question of whether Islam is compatible with democracy. 
ISLAM, DEMOCRACY, AND SOCIAL MOVEMENTS

The prevailing media and intellectual circles in the West perceive Islam at the root of the authoritarian polity in the Muslim Middle East. ${ }^{4}$ To them, Islam is patriarchal and lacks any concept of citizenship and freedom, since its belief in God's sovereignty has diminished popular power. The religion of Muhammad, instead of being a private matter, is essentially political. ${ }^{5}$ Islam embodies, it is claimed, a "world in which human life doesn't have the same value as it does in the West, in which freedom, democracy, openness and creativity are alien". ${ }^{6}$ Such views have been energized by many home-grown Islamists who, in the name of their religion, suspect democracy as a "foreign construct" and suspend popular will in favor of God's sovereignty. Let us call these Islamists "skeptics". In contrast to the skeptics, there are the "optimists", who tend to project an inherently democratic spirit of Islam, claiming it to be a religion of tolerance, pluralism, justice, and human rights. ${ }^{7}$ Rashid al-Ghanoushi, for instance suggests that "Islamic rule is by nature democratic". According to optimists, the Quranic notion of Shura (consultation) is to ensure the compatibility of Islam with democracy, and its valuation of human beings by their piety is to imply equality in race and gender and free will. In addition, the God-given "sovereignty of

4 For instance, a number of influential academics in the United States such as Eliot Cohen of Johns Hopkins University and Kenneth Adelman of the Defense Department's Defense Policy Board have suggested that Islam is essentially intolerant, expansionist, and violent. Some Evangelical Protestants have declared Islam an "evil" religion (quoted in William Pfaff's article in the Herald Tribune, December 5, 2002).

5 Bernard Lewis, “The Roots of Muslim Rage”, Foreign Policy, vol 17, no. 4. Summer 2001/2002.

6 Expressed by Israel's foremost "revisionist historian”, Benny Morris, cited in Joel Beinin, "No More Tears: Benny Morris and the Road from Liberal Zionism”, Middle East Report, no. 230, Spring 2004, p. 40. The essentialist perspective can be a self-defeating teleology, because if Islam is by essence undemocratic and against individual freedoms, then what can be done about it, particularly by the skeptics? What can be done in order to have Muslim societies head for a democratic future, in the sense of creating the ability to change governments by free elections, plus independent judiciary, freedom of speech, rule of law, minority rights? The solution for democratization seems to be either to convert Muslims into other "democratic religions" or to secularize them. I have no further comment on such "solutions"!

7 This camp may include authors such as John Voll, and Khaled Abou el-Fadl among others, as well as institutions like the Center for the Study of Islam and Democracy (USA), the Center for Muslim Democrats (France), and many websites. 
umma" underlies democratic governance based upon pluralism, difference and human rights. ${ }^{8}$

Methodologically, both the skeptics and the optimists share in their approach an exclusive commitment to texts, drawing their usually philosophical arguments on the literal reading of sacred scriptures (the Quran and Hadith), and pay astonishingly little attention to what these texts mean to the fragmented Muslim humanity in their day-to-day lives. There is rarely a discussion, moreover, on how these meanings vary in different historical junctures.

A central thrust of my argument is that "sacred" injunctions are matters of struggle, of competing "readings". They are, in other words, matters of history; humans define their truths. The individuals or groups that hold social power can assert and hegemonize those truths. The plurality of various theological genres - "liberation theology", "feminist theology", "queer theology", "green theology", and I like to add, "republican theology" - is a testimony to how different social and interest groups (such as the poor, women, the gays, religious environmentalists, and religiously oppressed) define their religious truths.

Is Islam then compatible with democracy? My contention is that this is the wrong question to pose in the first place. Why is that so? To be begin with, the "Islam vs. democracy" debate centers almost exclusively on one side of the equation, Islam, as if, the other side, democracy, is free from complexities. What does the term mean, after all? Is "democracy" equal to Robert Dahl's "polyarchy" - a consensual government by competing elites representing different social interests in a pluralist framework?" If so, where do the other domains of public life - economy, society and culture - stand? How do we account for individualism - as a prerequisite for democracy or its antithesis? Is capitalism with its corporate power and mighty manufacturing of consent not un-democratic? These questions are as old as the history of democracy itself. They have been raised by a host of movements and critiques which have sought to make democracy democratic. Marxism has highlighted the conflict of economic liberalism and democratic ideals; of Iraq", in Richard Bulliet (ed.), Under Siege: Islam and Democracy, Middle East Institute, Columbia University, occasional paper, no. 1, 1994, pp. 24-31. See also John Esposito, Islam and Democracy, Oxford: Oxford University Press, 1996.

9 Robert Dahl, Democracy and It's Critiques, Ithaca: Yale University Press, 1989. 
Social Democracy and "associationalism" have emphasized citizenship and equality. ${ }^{10}$ And Feminists have for long taken the issue with democratic theory for dismissing structural inequality, patriarchy, and the separation of public (domain, in which all are to be equal) and private i.e., the sphere of family and interpersonal relationships which they think are exploitative. ${ }^{11}$

More importantly, the question is not whether Islam is or is not compatible with democracy or by extension modernity (however understood), but rather under what conditions Muslims can make them compatible. Because there is nothing intrinsic in Islam, and for that matter any other religion, which makes them inherently democratic or undemocratic. We, the social agents, determine the inclusive or authoritarian thrust of religion. Because from this perspective, religion is nothing but a body of beliefs and ideas which invariably makes claims to authentic meaning, to a higher truth. Regardless whether religious beliefs and experiences relate to supernatural reality, in the end, as James Beckford notes, "religion is expressed by means of human ideas, symbols, feelings, practices, and organizations". ${ }^{12}$ In a sense, religious injunctions are nothing but our understanding of them - they are what we make them to be.

Some fifty years ago, many social scientists believed that Christianity and democracy were incompatible. ${ }^{13}$ But today the most deep-rooted democracies are in the Christian heartland, even though, I should add, fascism also emerged, and was associated with the Church, in the heartland of Christianity. As a matter of fact, authoritarian and exclusivist discourses associated with Christianity have not been uncommon. Early Christian sects promoted loyalty to authoritarian rulers, as long as they were not atheists and did not harm the believers. Obedience was at the heart of Christian political thought, on the ground that higher powers were ordained by God. "Those who sit in the office of magistrate", proclaims Martin Luther, "sit in

10 For an excellent discussion see David Held, Models of Democracy, Cambridge, Polity Press, 1996.

11 See: C. Peteman, Sexual Contract, Cambridge: Polity Press, 1988. For a very useful discussion on how economic freedom can undermine civil and political freedoms, see Sylvia Chan, Liberalism, Democracy and Development, Cambridge: Cambridge University Press, 2002.

12 James Beckford, Social Theory and Religion, Cambridge: Cambridge University Press, 2003, p. 2.

13 In addition, influential thinkers conclude that Catholicism and democracy were hardly compatible from the first world war on. See Lipset, Seong and Torres, "A Comparative Analysis of the Social Requisites of Democracy”, International Social Science Journal, vol. 136 (May 1993), p. 29. 
the place of God, and their judgment is as if God judged from haven". And Luther goes on, "If the emperor calls me, God calls me" ${ }^{14}$ As it is well known, the early Christian accommodation with authoritarian power led to a tragic anti-Semitism enshrined by biblical interpretation of the Crucifixion for which the Jews, not the Romans, were claimed to be responsible. ${ }^{15}$ Even today, there are some staunch Christians who would proclaim democracy as the "cause of all world problems". Because for them democracy as the invention of Satan is not founded on God's wish, but on the will of the "sinful humans" who would demand "abortion laws, anti-death penalty laws, gay rights" and such. ${ }^{16}$ Today there are many among the Evangelical Christians who deplore the practice of democracy in the United States because it has defied God's intention - a God who, in their view, gave the United States the "irresistible blessings" of biblical capitalism that is unknown in Europe. ${ }^{17}$ Such views might represent the voices of groups of Christian extremists, but no less than the Vatican leadership lashed out in September 2000 at the idea of "religious pluralism", pronouncing non-Christian creeds as flawed and "defective" and their believers as being in a "gravely deficient situation".

Yet despite this history, probably few lay Christians today would read their Bible in those authoritarian terms as Luther, or today's "Christian outlaws" would, or treat their creed in such exclusive fashion as the Vatican does. The point is that in all of these cases I described, the protagonists deploy sacred, biblical, scriptures to justify their claims. Thus, in an ironical twist from the anti-Semitism of early Christian Church, we observe today how the "fundamentalist Christians" in the US, in their fantastical quest to expedite the Judgment Day and speed up the return of Christ on earth, make political-theological alliance with the Jewish state in Israel.

14

\section{culture” (See Gregory S. Paul, “The Great Scandal: Christianity's Role in the Rise of the}

Nazis”, in Free Inquiry Magazine, vol. 23, no. 4. See also Klaus Scholder, The Churches and the

Third Reich, vols. 1 and 2, Philadelphia, Fortress Press, 1988. Beth Griech-Polelle, Bishop von

Galen: German Catholicism and National Socialism, New Haven, Yale University press, 2002.).

16 http://www.rossbishop.com/PDF/Fundamentalist\%20God.pdf

17 Cited in the very fine essay by Jeff Sharlet, "Through a Glass, Darkly: How the Christian

Right is Reimagining U.S. History”, Harper's Magazine, vol. 313, no. 1879, December 2006,

p. 36. For a detailed study of the US Evangelical Christian view on democracy and some of their practices see Kevin Phillips, American Theocracy, New York, Viking, 2006. 
In other words, we, the social actors render a religion, inclusive or exclusive, mono-vocal or pluralist, democratic or authoritarian..$^{18}$ Resorting to mere scriptures to determine the democratic thrust of religions, Islam for instance, will not take us very far. Not only because, as scholars Nasr Hamed Abu-Zayd and Khaled Masud have shown, ambiguity, multiple meaning and disagreement are embedded in the Quran and Hadith, ${ }^{19}$ but because individuals and groups with diverse interests and orientations may find their own often conflicting truths in the very same scriptures. Rather than resorting to the Quran or Shria'a to make sense of Osama Bin Laden, or Islamist radicalism in general, we need to examine the conditions that allow social forces to render a particular reading of the sacred texts hegemonic. And this is closely linked to a group's capacity to mobilize consensus around their truth. As I have argued, mere reference to scriptures may not serve as a useful analytical tool, yet it is at the core of the political battle to hegemonize discourses. Thus, stating that "Islamic rule is by nature democratic" (Ghanoushi) might be naïve analytically; but it is an expression of the struggle to make Islamic rule democratic. It is true that efforts to make a religion democratic undoubtedly start at an intellectual level. The challenge, however, is to fuse democratic interpretations into popular consciousness.

Foucault's emphasis on the power of words, of text, the power of discourse is well-known. Undoubtedly, his stress on taking the discourse seriously has been instructive. Yet, I suggest, we may equally dispute Foucault's unqualified claims by arguing that power does not simply lie in words, in

18 The most conspicuous manifestation of what Michael Lowy calls the "war of Gods" in recent times was in Latin American Catholicism, where Christians were deeply divided on whether to support or to oppose democracy. See Michael Lowy, The War of Gods: Religion and Politics in Latin America, London, Verso, 1996.

19 Nasr Abu-Zeid has advocated that Muslims should go beyond hermeneutically interpreting the scriptures for which they are bound to disagree. Disagreement, multiple meanings, and ambiguity, he argues, are embedded in the Quran itself. Similarly, the fiqh scholar Khaled Masud suggests that the ambiguity in and conflicting ahadith indicate the plurality of views on many religious matters at the time of the Prophet. See Nasr Abu Zayd, Rethinking the Quran: Towards a Humanistic Hermeneutics, Utrecht, Humanistics University Press, 2004. Professor Khaled Masud's statement is based on my personal communication with him. My contention is that irrespective of the truth of their arguments, Abu-Zayd and Masud's scholarly interventions account for an aspect of the struggle to see Islamic texts in different lights. 
the "inner truth" expressed in words, but primarily in those who utter them, those who give truth/power to these words. Discourse is not power, unless it is given material force. Perhaps what we should look for is not just what the discourse is, but especially where the power lies. The idea that, say, "Islam being compatible with democracy", has a different weight depending on who expresses it. It is not enough to utter right ideas, but there is a need to give them material force, to mobilize consensus around them. And this inevitably brings us to the realm of social-movement theory and practice, which, I suggest, mediate between discourse and power, between the word and the world.

Nowhere is this mediation so vivid as in the spectacular ability of the United States' Christian Right in turning its religious discourse into truth. It has been achieved by a systematic mobilization of the grassroots as well as cultivating support in the nation's highest decision making bodies, including some 230 legislators (in 2005 US Congress). Christian Right activists spread their theology through controlling over 2,000 radio stations, 250 Christian T.V. stations, thousands of church congregations, establishing numerous universities and colleges, and home-schooling at least two million children. They have managed to market over 60 million copies of the evangelical novel series, Left Behind. They have altered American history text books, produced alternative narratives in many subjects with the Christian message that advocates a "literal" reading of the Bible. The impact of such massive doctrinal mobilization should not be surprising - beyond the 50 million American Fundamentalist Christians, some 60\% of all Americans (according a Time/CNN poll) believe that predictions in the Book of Revelation, particularly of Judgment Day, will come true, and one out of four think that Bible predicted the 9/11 terrorist attacks. ${ }^{20}$

In short, the compatibility or incompatibility of a religion, including Islam, with democracy is not a matter of merely philosophical speculations, but of political struggle. It is not as much the question of texts as the balance of power between those who want a democratic religion and those who pursue an authoritarian version. Islamism and post-Islamism tell the story of these two social forces.

20 Most statistics in this passage come from Glenn Scherer, "The Godly Must Be Crazy", on the website of Monterey Institute of International Studies; see http://www.grist.org/news/ maindish/2004/10/27/scherer-christian/. 


\section{ISLAMISM：MOVEMENT AND WORLD VIEW}

In its high degree of generality, Islamism emerged as the language of selfassertion to mobilize those largely middle class high achievers who felt marginalized by the dominant economic, political or cultural processes in their societies, those for whom the perceived failure of both capitalist modernity and socialist utopia made the language of morality (religion) a substitute for politics. In a sense, it was the Muslim middle class way of rejecting what they considered as their excluders - their national elites, secular governments, and these governments' western allies. Hence, they rebuffed "western cultural domination", its political rationale, moral sensibilities, and normative symbols, even though in practice they shared many of those traits as in their neck-ties, food, education, and technologies. In contrast, those who enjoyed and prospered under the modern socio-economic and cultural conditions of globalization adhered to a different kind of Islam, the so called "moderate" Islam or more precisely "passive piety", if they were not secular.

In a quest to operate within an "authentic" nativist ideology, the Islamists tried to articulate a version of Islam that could respond to their political, economic and cultural deficits. So Islamism imagined Islam as a complete, divine system, with its superior political model, cultural codes, legal structure and economic arrangement - a system that responds to all human problems. More importantly, this Islam was to offer Muslims a sense of selfrespect, self-confidence, and a discursive autonomy. Such a perception of Islam, often accompanied by a strong populist language and heavy-handed social control, would inevitably marginalize and even criminalize many of those who remained outside of its strictures - the non-conformists, seculars, non-Islamist Muslims, religious minorities, and many women. At the core of the Islamist paradigm, then, lies a mix of piety and obligation, a blend of devotion and duty.

Contemporary Islamism in the Middle East, as a movement and discourse, is clearly an historical phenomenon, which gained currency since the 1970s. I think two simultaneous but contradictory processes pushed Islamism in to its hegemonic position: opportunity and suppression. The "opportunity" for a massive educational expansion, economic development, virtual abundance of wealth (oil money) and a general social mobility, went hand-in-hand with continuous political repression, marginalization and a growing inequality. (In the 1950s, there were only ten Universities in the Arab world. Currently there are over two hundred). Particularly critical at 
this juncture was that the middle class marginals, now overwhelmingly educated, were becoming acutely aware of their marginalization and consequently experienced a strong "moral outrage". They directed their outrage against the national states and the elites which had invariably allied with the Western powers, chiefly the USA, the very government that, ironically, favored Islamic opposition as a bulwark against both communism and secular nationalism. In the Arab world in particular, the political classes considered the long-standing occupation of the Palestinian lands by Israel and the US support for this, as further evidence of their subjugation at the broader global level. Intransigent Israeli policy of occupation (in particular under the rightist Likud governments) often assumed such a central place in Arab/ Muslim popular sentiments that the people's struggle to regain "dignity", that is, to free Arab lands, often overshadowed their quest for democracy. In other words, freedom from foreign domination would take precedence over freedom at home.

Induced by the Islamist populist language, some observers tend to associate the Islamist movements in the Middle East with Latin American liberation theology. While one can readily acknowledge the common religious frames, in my judgment there is little ground to compare the two. Liberation Theology began as an attempt to reform the Church from within, but evolved into a social movement in which the concerns of the dispossessed occupied a central place. Liberation Theology aimed to transform the oligarchic disposition of the Catholic Church and its neglect of the poor, in the conditions where socialist movements (notably the Cuban Revolution) by raising the banner of social justice had pushed the Church on to the brink of social irrelevance. Led by socially-conscious theologians, the strategic objective of Liberation Theology was the "liberation of the poor"; its interpretation of the Gospel followed from this strategic ambition.

In contrast, Islamism, despite its variation, has had broader social and political objectives than simply the poor. Its primary concern has not been social development, nor attention especially to the plight of the poor, but building an "ideological community" - establishing an Islamic state, or implementing Islamic laws and moral codes. Only then could the poor expect to profit from an Islamic moral trickle down. In short, Middle Eastern Islamist movements and the Latin American Liberation Theology represent two quite different social and political trajectories.

If anything, the Islamist movements, especially radical Islamism in the Middle East, exhibit resemblances to the Latin American guerrilla move- 
ments of the 1960s and 1970s - not of course in their ideologies, but relative to their actors and the conditions under which they emerged. The rise of both movements may be traced to the simultaneous conditions of both social transformation (rapid urbanization, mass schooling, higher education and an expectation of mobility) as well as social exclusion, of those whose dream of economic mobility was dashed by unjust social and political structures. However, of course, different global contexts gave the two movements different ideological frameworks: secular leftism of the guerrilla movements in Latin America versus radical religion of the Islamist movements.

In the Muslim Middle East, the political class par excellence remains the educated middle class - state employees, students, professionals and the intelligentsia - that mobilized the "streets" in the 1950s and 1960s with overarching ideologies of nationalism, Ba"thism, socialism and social justice. Islamism has been the last of these grand worldviews. With the core support coming from the worse-off middle layers, Islamist movements succeeded for three decades in activating large numbers of the disenchanted population with what I like to call cheap Islamization, that is, by resorting to the language of moral and cultural purity (e.g. by calling to restrict alcohol, “immoral" literature and raising issues with women's pubic appearance), appealing to identity politics, promising a highly general utopian future and carrying out affordable charity work. However, by the mid-1990s, it became clear that Islamists could not go very far when it came to a more costly Islamization, that is, establishing an Islamic polity and economy and conducting international relations compatible with the modern national and global citizenry. Consequently, Islamist rule faced profound crisis wherever it was put into practice (as in Iran, Sudan, or Pakistan); and the violent strategies, and armed struggles, that the radical Islamists had adopted, failed to make major inroads (as in Egypt and Algeria). In short, the Islamist movements were either repressed by the authoritarian states, or compelled to revise their earlier outlooks. Many Islamists departed from their earlier totalizing discourse or violent methods, and began to develop a more democratic vision on their Islamic projects.

This, however, did not end the political role of Islam altogether. Global and domestic social and political conditions have continued to generate appeals for religious and moral politics, especially in those nations that had not experienced Islamism. Anti-Islamic sentiment in the West following the 9/11 events, and the subsequent war on terrorism reinforced a pro- 
found feeling of insecurity and outrage among Muslims who sensed that Islam and Muslims alike had come under a global onslaught. This in turn, increased the appeals for languages of religiosity and nativism. Several Islamic parties (e.g. Justice and Development in Morocco, Islamist Parties in Algeria, religious alliance in Pakistan, Bahrain and Turkey) which, among other things expressed opposition to the US policies in Afghanistan were considerably successful in nationwide elections in 2002. However, these electoral victories pointed less to a revival of Islamism than to a shift from political Islam into fragmented languages concerned with personal piety and a global, anti-Islamic menace. Indeed, many Muslim societies were on the brink of a post-Islamist turn.

\section{What is Post-ISLAMISM?}

The term post-Islamism has a relatively short history. In 1995, I happened to write an essay entitled the "Coming of a Post-Islamist Society" 21 in which I discussed the articulation of the remarkable social trends, political perspectives, and religious thought which post-Khomeini Iran had begun to witness - a trend which eventually came to embody the reform movement of the late 1990s. My tentative essay dealt only with the societal trends for there was little at the governmental level that I could consider "post-Islamist". Indeed as originally used, post-Islamism pertained only to the realities of the Islamic Republic of Iran, and not to other settings and societies. Yet the core spirit of the term referred to the metamorphosis of Islamism in its ideas, approaches, and practices, from within and without.

Since then, a number of prominent observers in Europe have deployed the term, even though often descriptively, to refer primarily to what they consider a general shift in attitudes and strategies of Islamist militants in the Muslim world. ${ }^{22}$ Unfortunately, post-Islamism has been presented and perceived primarily as an historical rather than an analytical category, rep- 
resenting a particular era or an historical end. Thus, partly due to its poor conceptualization and partly for its misperception, the term has attracted unwelcome reactions. Critics have correctly disputed the premature generalization about the end of Islamism. ${ }^{23}$ What seems to be changing, the critiques argue, is not political Islam (i.e., doing politics in an Islamic frame) but only a particular, "revolutionary", version. ${ }^{24}$ Post-Islamism, they argue, does not signify a distinct reality, but merely one variety of Islamist politics. $^{25}$

In my formulation, post-Islamism represents both a condition and a project, which may be embodied in a master (or multi-dimensional) movement. In the first instance, post-Islamism refers to a political and social condition, in which after a phase of experimentation, the appeal, energy, and sources of legitimacy of Islamism get exhausted even among its onceardent supporters. Islamists become aware of their system's anomalies and inadequacies as they attempt to normalize and institutionalize their rule. The continuous trial and error makes the system susceptible to questions and criticisms. Eventually, pragmatic attempts to maintain the system reinforce abandoning certain of its underlying principles. Islamism becomes

Islamism" as an increasingly fragmented and "ethnized" world-view due to growing reinterpretations and localization of Islamism; see Reinhard Schulze, "The Ethnization of Islamic Cultures in the Late $20^{\text {th }}$ century or From Political Islam to Post-Islamism”, in George Stauth (ed.) Islam: Motor or Challenge of Modernity, Yearbook of the Sociology of Islam, no. 1, 1998, pp. 187-198. In turn for Gilles Kepel in his Jihad: The Trial of Political Islam (2 $2^{\text {nd }}$ ed., London: I.B. Tauris, 2002, p. 368), the term describes the new orientation of some Islamists who in the name of democracy and human rights have departed from radical, Jihadi and salafi doctrines. Others fall short of conceptualizing the term altogether. One exception is Farhad Khosrokhvar's treatment of the term when assesses the views of some 'post-Islamist Intellectuals in Iran' such as Abdul Karim Soroush. See Farhad Khosrokhavar, "The Islamic Revolution in Iran: Retrospect after a Quarter Century”, Thesis Eleven, vol. 76, no. 1, 2004.

23 For instance, see: Diaa Rashwan, "Wishful Thinking, Present and Future", Al-Ahram Weekly, 7-13 February 2002.

24 See: Alain Roussillon, “Decline of Islamism or the Failure of Neo-Orientalism?” (in Persian), Goft-o-gu, no. 29, Fall 1379, pp. 163-185, Tehran.

25 See for instance: Salwa Ismail, "The Paradox of Islamist Politics", in Middle East report, 221, winter 2001, pp. 34-39. See also Francois Burgat, Face to Face with Political Islam, London, I.B. Tauris, 2003, pp. 180-181. Only very recently, Olivier Roy came up with a definition post-Islamism as the "privatization of re-Islamization". It refers to individualized "neofundamentalism”. See O. Roy, Globalised Islam: The Search for a New Ummah, London, Hurst and Co., 2004, p. 97. The way I use the term is fundamentally different. 
compelled, both by its own internal contradictions and by societal pressure, to reinvent itself, but does so at the cost of a qualitative shift. The tremendous transformation in religious and political discourse in Iran during the 1990s exemplifies this tendency.

Not only a condition, post-Islamism is also a project, a conscious attempt to conceptualize and strategize the rationale and modalities of transcending Islamism in social, political, and intellectual domains. Yet, post-Islamism is neither anti-Islamic nor un-Islamic or secular. Rather it represents an endeavor to fuse religiosity and rights, faith and freedom, Islam and liberty. It is an attempt to turn the underlying principles of Islamism on its head by emphasizing rights instead of duties, plurality in place of singular authoritative voice, historicity rather than fixed scriptures, and the future instead of the past. It wants to marry Islam with individual choice and freedom, with democracy and modernity, to achieve what some have called an "alternative modernity". Post-Islamism is expressed in such beliefs that "we don't mind demolishing mosques in order to build freeways", in acknowledging secular exigencies, in freedom from rigidity, in breaking down the monopoly of religious truth. In short, whereas Islamism is defined by the fusion of religion and responsibility, post-Islamism emphasizes religiosity and rights.

In Iran, the end of the war with Iraq (1988), the death of Ayatollah Khomeini (1989), and the program of post-war reconstruction under President Rafsanjani marked the onset of post-Islamism. As a master movement, Iran's post-Islamism was embodied in remarkable social and intellectual trends and movements - expressed in religiously innovative discourses by youths, students, women, and religious intellectuals, who demanded democracy, individual rights, tolerance, and gender equality as well as the separation of religion from the state. Yet they refused to throw away religious sensibilities altogether. The daily resistance and struggles of ordinary actors compelled religious thinkers, spiritual elites, and political actors to undertake a crucial paradigmatic shift. Scores of old Islamist revolutionaries have renounced their earlier ideas, lamenting the danger of the religious state to both religion and the state. In a sense, the Islamic state generated adversaries from both without and within, who called for the secularization of the state but stressed the maintaining religious ethics in society.

Is post-Islamism then an exclusively Iranian phenomenon? The truth is that while the Islamic Revolution acted in the 1980s as the demonstration effect to bolster similar movements in other Muslim countries, Iran's 
post-Islamist experience has also contributed to an ideological shift among some Islamist movements. Nevertheless, internal dynamics and global forces since the early 1990s have played a greater role in instigating a postIslamist turn among individual movements in the Muslim world. The new pluralist strategy of the Lebanese Hizbullah in the early 1990s leading to a split in the movement, the emergence in the mid-1990s of Al-Wasat party in Egypt as an alternative to both militant Islamists and the Muslim Brothers, the pluralism of Islamic parties in Turkey (Rifah, Virtue, and Justice and Development Parties), the discursive shift in Indian Jamat-i Islami towards more inclusive, pluralistic and ambiguous ideological dispositions ${ }^{26}$ and finally the emergence in Saudi Arabia of an "Islamo-liberal" trend in the late 1990s seeking a compromise between Islam and democracy, ${ }^{27}$ each displays some diverse versions of post-Islamist trends in Muslim societies today. In each of these cases, post-Islamism denotes a departure, albeit in diverse degrees, from an Islamist ideological package which is characterized by universalism, monopoly of religious truth, exclusivism, and obligation, towards acknowledging ambiguity, multiplicity, inclusion and compromise in principles and practice. I should stress that, first, Islamism and postIslamism serve primarily as conceptual categories to signify change, difference, and the root of change. In the real world, however, many Muslims may adhere eclectically and simultaneously to aspects of both discourses. On the other hand, the advent of post-Islamism as a real trend, should not be seen necessarily as the historical end of Islamism. What it should be seen as is the birth, out of Islamist experience, of a qualitatively different discourse and politics. In reality we may witness simultaneous processes of both Islamization and post-Islamization.

In conclusion, I know that these days the headlines and discussions in the newsrooms present a different picture. The mainstream media are filled with graphic stories and images of conflicts and killings, of bombings and burnings. It is as if "clash" has, indeed, become the truth of our current

26 See: Irfan Ahmad, From Islamism to Post-Islamism: Jama'at-i Islami of India, PhD dissertation, University of Amsterdam, January 2005.

27 For an analysis of Saudi Arabia's "Islamo-Liberal" trend or reform movement, see: Stephane Lacroix, "A New Element in the Saudi Political-Intellectual Field: The Emergence of an Islamo-Liberal Reformist Trend", unpublished paper presented in Workshop “Saudi Futures: Trends and Challenges in the Post-9/11 Post-Iraq-War World, Leiden, 20-21 February 2004, Leiden, Netherlands. 
"civilizations". In response to these tales of the mainstream, I would like to invoke Will and Ariel Durant's profound observation on how to understand and narrate the story of our civilization:

"Civilization is like a stream with banks. The stream is sometimes filled with blood from people killing, stealing, shouting and doing things historians usually record; while on the banks, unnoticed, people build homes, make love, raise children, sing songs, write poetry and even whittle statues. The story of civilization is the story of what happened on the banks." 28 

Asef Bayat (Ph.D, University of Kent 1984) is the Academic Director of the International Institute for the Study of Islam in the Modern World (ISIM), and the ISIM Chair at Leiden University. He taught sociology and Middle East studies at the American University in Cairo. He has held visiting positions at the University of California, Berkeley, Columbia University and the University of Oxford. His academic interests range from political sociology, social movements, to urban space and politics, international development, contemporary Middle East, and Islam and the modern world. He has conducted ethnographic research in the areas of popular mobilization in the Iranian Revolution, labor movements, politics of the urban poor, development NGOs, everyday cosmopolitanism, comparative Islamisms, and Muslim youth cultural politics, primarily in Iran and Egypt. 
INTERNATIONAL INSTITUTE

FOR THE STUDY OF ISLAM

IN THE MODERN WORLD (ISIM)

Visiting address:

Rapenburg 59

2311 GJ Leiden

The Netherlands

Postal address:

P.O. Box 11089

2301 Eв Leiden

The Netherlands

Telephone:

+31-(0)71-527 7905

Fax:

+31-(o)71-527 7906

E-mail:

info@isim.nl

Website:

www.isim.nl 